\title{
The Woman and Her Wellbeing
}

\author{
Ijeoma Ijeaku* \\ Assistant Clinical Professor of Psychiatry, UC Riverside School of Medicine, USA
}

Submission: December 14, 2018; Published: December 17, 2018

*Corresponding author: Ijeoma Ijeaku, Assistant Clinical Professor of Psychiatry, UC Riverside School of Medicine, USA.

\section{Opinion}

With constant and persistent influx of information, she is bombarded with all sorts of data about who she should be, what she should do, where she should do it, how she should do it and why she should do it... With continuous blurring of the lines that originally defined gender roles and a need to redefine herself, the woman is constantly seeking new heights to conquer and creating new roles for herself...

With society calling her angry when she wants to be heard or soft when she shares her caring nature or weak when she considers all of her options... With an ever changing landscape, a new world so to speak, a world that claims to prescribe equal rights to all genders, arises this new woman who is definitely here for good...

a) She is beautiful and celebrates it...

b) She is smart and owns it...

c) She is full of passion and has no apologies...

d) She is her own person and the rules are hers and hers alone...

She stands in all her glory representing all the women that have come before her; the ones who could not acknowledge their beauty or smarts or passion or personality for fear of being judged and found to be less...

She's creating new businesses, presiding over countries and other agencies, building up Fortune 500 companies, heading families, having babies up to menopause and sometimes even beyond, choosing her partner in life and in business for reasons solidly her own, operating on the child's brain and engaging the child in play and other types of therapies...

To be all of the above and still stand, she needs to make selfcare her mantra. She has to embrace wellness. She has to strike the balance that allows her enjoy all that she has worked hard for... Dear Woman, you have earned it! You have become who you wanted to become. You are playing the exact roles you have chosen for yourself! You are doing what your mother and grandmother never dreamed was possible and you are doing it so well. You do not have to prove yourself anymore; you are it!

Whether you choose to hang out with your friends or family or colleagues or meditation group members or all of the above, that's your choice! But you must have confidants to share your innermost thoughts and feelings with. You must have your support, your safe place...

You may love mindfulness techniques or yoga or zumba or jazzercise or something else but you need to have a real outlet, a space that allows you unleash the real you...Whether you choose to get your annual check-up during your birthday or during other events, you must pay attention to your physical health. Are you eating right? Are you getting your screening tests done? Are you optimizing your sleep? Are you staying as active as possible?

Whether you identify as religious or spiritual, you must create meaning and purpose in your life. Are you just going through the motions? Are you just getting through another day? Another routine? You must embrace the idea that you totally have a brand to sell and that the only way to do this is in excellence... Whether you believe in psychiatry or not, you must pay attention to your mental health and mental well-being. Are your behaviors lining up with your values? Are your choices representative of your true ? Are you keeping it real?

Dear Woman, take care that you live a wholesome life so that your work and the work of those that have come before you will not be in vain...cheers! 
(C) This work is licensed under Creative

BY DOI: 10.19080/JGWH.2018.13.555867
Your next submission with Juniper Publishers will reach you the below assets

- Quality Editorial service

- Swift Peer Review

- Reprints availability

- E-prints Service

- Manuscript Podcast for convenient understanding

- Global attainment for your research

- Manuscript accessibility in different formats ( Pdf, E-pub, Full Text, Audio)

- Unceasing customer service

Track the below URL for one-step submission https://juniperpublishers.com/online-submission.php 